11. Lexicon of Iraq War Lingo: Fightin' Words, October 18, 2007. URL: http:// www.motherjones.com/news/feature/2007/11/iraq-war-glossary.html.

12. War Slang. URL : http://www.globalsecurity.org.

DOI https://doi.org/10.30525/978-9934-26-180-0-16

\title{
МОВНІ ОДИНИЦІ КАТЕГОРІЇ НЕВИЗНАЧЕНОСТІ У ОПОВІДАННІ ЛЮСІ КОЛДУЕЛ $A L L$ THE PEOPLE WERE MEAN AND BAD
}

\begin{abstract}
Давиденко Н. I.
асистент кафедри перекладу та слов'янської філології

Криворізький держсвний педагогічний університет

м. Кривий Ріг, Дніпропетровська область, Украӥна
\end{abstract}

У роботі розглядаємо особливості функціонування у художньому дискурсі одиниць категорії невизначеності різного рівня. Реалізація на мовному рівні такої провідної складової поняттєвого апарату сучасної лінгвістики як принцип невизначеності, який має здатність значно розширювати можливості того, хто говорить в цілях досягнення певного прагматичного ефекту [3, с. 30] привертає увагу все більшої кількості лінгвістів. Мовні одиниці, які належать до досліджуваної категорії, визначаються як слова-обмежувачі та трактуються як лексичні одиниці, що розмивають межі екзістенціонального. Основним аргументом для такого рішення $\epsilon$ здатність подібних мовних засобів здійснювати семантичну корекцію, вносячи до семантики модальне забарвлення приблизності [4, с. 67].

Досліджуване поняття, хоча і не має чіткого визначення у системі мови, лежить в основі походження усіх речей. Останні дослідження наголошують, що визначеність вважається вторинною по відношенню до невизначеності. 3'ясовано, що у процесі зображення дійсності мозком людини, нестабільність та непередбачуваність сучасного життя, корелює 3 інтенсивним ростом у мові форм вираження категорії невизначеності.

Роботу виконано на матеріалі оповідання авторки з Північної Ірландії Люсі Колдуел, All the People Were Mean and Bad (2021 р.), за яке цього року вона отримала національну премію $B B C$. Специфічною рисою оповідання $є$ використання відомого прийому розповіді від другої особи, що робить матеріал особливо цікавим для даного дослідження. У роботі 66 
проаналізовано особливості вживання експліцитних та імпліцитних одиниць категорії невизначеності, загальним обсягом 644 приклади.

3'ясовано, що займенники другої особи - уои та your (392 приклади), зазвичай використовуються для безпосереднього спілкування з читачем $\mathrm{i}$ залучення його до подій, описаних в історії. Two weeks after your cousin dies, you're on a night flight back to London from Toronto. Your phone battery is dead. Внаслідок такого розриву дистанції, завдяки вживанню зазначених займенників, читача втягують у розповідь, створюючи враження, що він сам головний персонаж, і це $є$ проявом невизначеності на рівні тексту.

Неозначений артикль a/an (128 прикладів), як найбільш універсальний морфологічний маркер на позначення невизначеності, вказує на те, що іменник називає певний предмет або ж явище, які ще невідомі читачеві або співрозмовнику: It certainly wasn't a holiday, trying to placate a baby in unfamiliar surroundings, endless hours wandering alone or lying in a hotel room trying to sleep.

На позначення категорії невизначеності у досліджуваному матеріалі, вживаються наступні лексичні маркери (98 прикладів):

- модальні дієслова: might (A new country, from which you might not have returned); could (You could email him, you think);

- епістемічні дієслова seem (It seems more than time and distance you're traversing); think (I think, he says, she needs a gin and tonic too?);

- займенники: one (No one could understand it); they (People are helpful, you say, they've been so helpful, every bit of the way - and it's true); it (You didn't do it again);

- займенникові словосполучення: some of / any of /many of / none of (These are some of the things you talk about);

- неозначені займенники: some (Your husband says you should take on some private rest); somehow (Somehow you manage to say it lightly); somewhere (Somewhere between the two?); sometimes (Sometimes you think, your daughter is the only person who feels real); any (Not even for any reason); anything (Anything for your wife?); anyone (I wouldn't wish that journey on anyone);

- прислівники часу: once (I once flew solo with the twins); eventually (We are all ashes and dust eventually); soon (I'm going to tactically misplace the book as soon as we get home); always (Is it always too late?); already (Because he's already been too kind to you); never (If we can never truly begin again); ever (No one, ever, told them they were going to die);

- квантифікатори: several (Several other red-eye flights have come in too); much (There's just so much space); many (In so many ways I still feel 24 myself); 
(a) little (Just a little over 3,000 miles); (a) few (You don't manage more than a few bites);

- іменники з узагальнюючим значенням: cousin (My cousin just died); thing (The first thing about architecture);

- апроксиматори: sort of (But at the same time he's sort of right); a kind of (Astray is also a kind of exile); that (I'm actually not that hungry);

До синтаксичних засобів на позначення невизначеності (26 прикладів) відносимо:

- екзистенціональну конструкцію there+to be (There is one page in the book that you like);

- неозначено - особові речення (You wait together as they fetch the buggy; But it wasn't what either of you had thought it would);

- питання накшталт риторичних: Who knows? But where to drive to, and when you got there, what to do?;

- оказіональне вживання прислівника now (- What are you going to do now? he says. - Now this minute now, or now in a more existential sense? You say).

Загалом слова категорії невизначеності, виступають як засоби авторизації та адресації, обслуговуючи надійність каналу зв'язку $[1$, c. 328], вони сигналізують про те, що автор висловлювання намагається обмежити відповідальність за сказане/дистанціюватися від сказаного; а читачу/слухачеві пропонується інтерпретувати наведені елементи, та/або домислити їх референти. Крім цього, досліджувані мовні одиниці, зменшуючи категоричність висловлювання, виконують функцію пом'якшення та надають ввічливості. Тобто, як зазначає С.М. Кишко, використання обмежувачів дозволяє мовцю реалізувати додаткову комунікативну інтенцію, яка полягає у навмисній деінтенсифікації категоричності повідомлення [2, с. 56].

Що стосується сфери вживання одиниць категорії невизначеності, то, з'ясовано, що вона поширюється як на художній, так і на спеціальні дискурси.

\section{Література:}

1. Катина Н. А. Функциональная специфика дискурсивных маркеров «Речевое отгораживание». URL: https://cyberleninka.ru/article/n/ funktsionalnaya-spetsifika-diskursivnyh-markerov-rechevoe-otgorazhivanie

2. Кишко С. Н. К вопросу о плане выражения категории модерации. Научные записки. Кировоград, № 2, 2008. 54 с.

3. Мартынова И. А. Лексические маркеры неопределенности в разговорном англоязычном дискурсе. URL: https://cyberleninka.ru/article/n/ 
leksicheskie-markery-neopredelennosti-v-razgovornom-angloyazychnomdiskurse

4. Песина С. А., Пулеха И. Р., Калашник Д. М. Лингвокогнитивный подход к интерпретации категории неопределенности (на материале английского языка). URL: https://cyberleninka.ru /article/n /lingvokognitivnyy-podhod-k-interpretatsii-kategorii-neopredelennosti-na-materialeangliyskogo-yazyka

DOI https://doi.org/10.30525/978-9934-26-180-0-17

\title{
«ПРОСНИСЬ, САМУРАЙ!»: К ВОПРОСУ ОБ ОСОБЕННОСТЯХ УПОТРЕБЛЕНИЯ ЯПОНИЗМОВ В КИБЕРПАНК-ЛИТЕРАТУРЕ
}

\author{
Донец П. Н. \\ преподаватель кафедры романо-германской филологии \\ и методики преподавания иностранных языков \\ Международный гуманитарный университет \\ г. Одесса, Украина
}

Киберпанк сегодня у всех на устах. Некогда «похороненный» своими же создателями, жанр без преувеличения переживает свой второй Ренессанс: к нему вновь обращаются писатели-фантасты, кинорежиссёры, художники, музыканты, аниматоры и разработчики видеоигр, активно интегрирующие в свои произведения киберпанковскую эстетику. Об одном из аспектов этой эстетики мы сегодня и поговорим.

Те, кто хоть раз погружались в мрачные и неприветливые миры киберпанка, наверняка обратили внимание на характерную для жанра деталь - обилие в повествовании японских элементов. В данном случае речь идёт не о киберпанке японского происхождения (там-то как раз их наличие абсолютно оправдано и уместно), а о его заокеанском родоначальнике: как мы помним, жанр зародился в США в начале 80-х годов.

Увлечённость фантастов-восьмидесятников Страной восходящего солнца - феномен достаточно хорошо изученный. На вопрос, почему киберпанк настолько японский, и откуда в нём возникли самураи, дзайбацу и якудза, не раз отвечали и сами писатели, и многочисленные исследователи их творчества. Суммируя сказанное ими, отметим, что эти причины имеют, по крайней мере, три измерения: социально-экономическое, философское и культурное. 